Katoro, A. V., \& Hertinjung, W. S. (2020). Perbedaan keterampilan sosial ditinjau dari sistem pendidikan. Indigenous: Jurnal Ilmiah Psikologi, 5(1). 35-43. doi: https://doi.org/10.23917/ indigenous.v5i1.6841

\title{
Perbedaan Keterampilan Sosial Ditinjau dari Sistem Pendidikan
}

\section{Aindha Vegalaras Katoroํㅜ, Wisnu Sri H ertinjung²}

Universitas Muhammadiyah Surakarta ${ }^{12}$

aindhav@gmail.com ${ }^{1}$,wisnu.hertinjung@ums.ac.id ${ }^{2}$

\begin{abstract}
The aims of this study were to know the social skills differences which are seen from education system, to know the level of the social skills of the students of government-affliated school and Islamic boarding school education system, to know the social skills of the students of government-affiliated school, and to know the social skills of the students of Islamic boarding school education system. The hypothesis of this study is that there are differences in the social skills between government-affiliated school students and Islamic boarding school where the social skills of government-affiliated school students are higher than Islamic boarding school students. The method used in this study is quantitative, while the scale of social skills is used as a method in collecting the data. The subjects of this study were collected by using cluster random sampling method. They are taken from the students of grade XI of SMAN X, the total amount is four classes and ninety eight students, and SMA PPTQ $X$, the total amount is four class and seventy seven students. The $t$-test is used to analyze the data. The result of $t$-test analysis is obtained $t$-test $=$ 5,744 with sig. $p=0,000 \leq 0,01$ which means there is a difference of social skills between students from government-affiliated school and from Islamic boarding school. The average of students from governmentaffliated school is 138,50 and the average of Islamic boarding school is 128,21 which mean the social skills of students from government-affiliated schools are higher than the social skills of students from Islamic boarding school. Students' social skills in both education systems have the same category, namely high. But the average of Islamic boarding school of 128,21 which shows that in the high category leads to medium. Based on the results of this study, the research hyphotesis proved.
\end{abstract}

Keywords: education system; social skills; islamic boarding school

Abstrak. Penelitian ini bertujuan untuk mengetahui perbedaan keterampilan sosial ditinjau dari sistem pendidikan yaitu untuk mengetahui tingkat keterampilan sosial antara siswa dengan sistem pendidikan negeri dan sistem pondok pesantren, serta mengetahui terkait keterampilan sosial pada masing-masing sistem pendidikan. Hipotesis dari penelitian ini adalah terdapat perbedaan keterampilan sosial antara siswa sekolah negeri dengan siswa sekolah pondok pesantren dimana keterampilan sosial siswa sekolah negeri lebih tinggi dibandingkan dengan siswa sekolah pondok pesantren. Metode yang digunakan dalam penelitian ini yaitu kuantitatif komparasi. Instrumen pengumpulan data menggunakan skala keterampilan sosial. Subjek penelitian diambil dengan teknik cluster random sampling. Subjekpenelitian adalah siswa kelas XI SMA Negeri X sebanyak 4 kelas yang berjumlah 98 siswa dan siswa SMA PPTQ $X$ sebanyak 4 kelas yang berjumlah 77 siswa. Analisis data menggunakan uji-t (t-test). Hasil analisis uji $t$ diperoleh $t$-hitung $=5,744$ dengan sig. $p=0,000 \leq 0,01$ yang berarti terdapat perbedaan yang sangat signifikan keterampilan sosial antara siswa sekolah negeri dan sekolah pondok pesantren. Rerata keterampilan siswa di sekolah negeri sebesar 138,50 dan rerata keterampilan sosial siswa di sekolah pondok pesantren sebesar 128,21 yang berarti keterampilan sosial siswa sekolah negeri lebih tinggi dibandingkan sekolah pondok pesantren. Keterampilan sosial siswa pada kedua sistem pendidikan memiliki kategori 
yang sama yaitu tinggi, hanya saja rerata sekolah pondok pesantren sebesar 128,21 yang menunjukkan kategori tinggi ke arah sedang. Berdasarkan hasil penelitian tersebut, maka hipotesis penelitian terbukti.

Katakunci: keterampilan sosial; sistem pendidikan; pondok pesantren

\section{PENDAHULUAN}

Kehidupan bersosial tidak hanya meliputi kalangan tertentu saja termasuk juga kalangan remaja. Masa remajadi kelompok sosial industri modern adalah masa peralihan dari anak-anak ke dewasa yaitu pada usia 11 - 19 atau 20 tahun (Papalia \& Feldman, 2014). Perkembangan perilaku sosial yang sesuai dapat diungkapkan individu dalam bentuk etika, perasaan, opini, pengharapan, dan penghormatan dari antar individu, penyelesaian masalah, serta penanggulangan konflik yang akan terjadi (Mota \& Matos, 2013).

Remaja dalam berinteraksi sosial membutuhkan keterampilan sosial. Keterampilan sosial merupakan kemampuan dalam berkomunikasi, menjalin hubungan dengan orang lain, menghargai diri sendiri dan orang lain, memberi atau menerima feedback seperti kritik, bertindak sesuai norma dan aturan yang berlaku (Majorsy, Kinasih, Andriani, \& Lisa, 2013). Hal tersebut tidak sesuai dengan hasil wawancara salah satu guru BK SMA Negeri X yang mengatakan bahwa masih ada perselisihan yang terjadi antar siswa, terkadang juga masih terjadi pertengkaran antar siswa sehingga guru BK turun tangan untuk menyelesaikan permasalahan tersebut.

Kasus lain yang pernah terjadi belakangan ini yaitu terdapat satu orang siswa Sekolah Menengah Pertama di Kota Sedati yang masuk rumah sakit karena menjadi korban cyberbullying pada tahun 2014 di akun media sosial facebook. Siswa tersebut merasa semua temannya membencinya akibat perilaku cyberbullying yang dialaminya melalui akun media sosial facebook. Pelaku yang menggunakan nama samaran di akun media sosial tersebut menghina, mengejek, dan mempermalukan korban yang terkenal sebagai siswa yang pandai (Sari \& Suryanto, 2016).

Penelitian lain mengenai kualitas hubungan antara remaja dengan lingkungan sebayanya menunjukkan hasil bahwa adanya keterikatan yang aman antar remaja dapat mengembangkan empati dan menampilkan perilaku yang tepat. Pengembangan keterampilan remaja dapat distimulasi dengan cara remaja lebih banyak terlibat dalam kegiatan teman sebaya dan lebih menjalin hubungan secara emosional dengan kelompok sebaya (Mota \& Matos, 2013). Berdasarkan data awal penelitian Bakhtiar (2015) di SMA Negeri 1 Bontonompo, menunjukkan bahwa adanya siswa yang bermasalah dalam keterampilan sosial dipengaruhi oleh faktor keluarga, persahabatan, solidaritas kelompok, dan kemampuan menyesuaikan diri. Sebanyak 36\% memilih setuju berada dalam keluarga yang tidak harmonis, 53\% susah dalam berinteraksi dengan lingkungan sekitar, $25 \%$ lebih mementingkan urusan pribadi daripada kelompok, dan sebanyak 63\% siswa merasa sulit untuk menyesuaikan diri.

Menurut Ketua Komisi Perlindungan Anak Indonesia dalam (Movanita, 2016), waktu yang panjang di sekolah akan mengganggu kehidupan sosial anak. Anak butuh berinteraksi dengan lingkungan sekolah, teman di lingkungan rumah, dan keluarga di rumah. Kondisi ideal pendidikan di Indonesia adalah ketika dua aspek pendidikan siswa terpenuhi yaitu pada jenjang SD siswa mendapat pendidikan karakter sebanyak $80 \%$ dan pengetahuan umum sebanyak $20 \%$. Jenjang SMP pendidikan karakter siswa terpenuhi sebanyak $60 \%$ dan pengetahuan umum sebanyak 40\%.

Ada tiga jenis lembaga pendidikan yaitu lembaga pendidikan formal, non formal, dan informal. Salah satu pendidikan formal yaitu sekolah menengah negeri atau SMA negeri. Sistem kurikulum yang diterapkan mengutamakan pemahaman, skill, dan pendidikan berkarakter. 
Sekolah negeri menuntut siswa untuk paham atas materi, aktif dalam berdiskusi, dan presentasi serta memiliki kesopanan dan kedisiplinan yang tinggi (Aqdwirida, 2016). Salah satu lembaga pendidikan yang menyelenggarakan dua jenis sistem pendidikan yaitu pondok pesantren. Pondok pesantren menyelenggarakan pendidikan secara formal dan informal untuk bidang agama yang berjalan secara beriringan. Siswa yang menimba ilmu di pondok pesantren sendiri disebut dengan santri (Anam \& Suharningsih, 2014). Perbedaan sistem pengajaran pada pondok pesantren yaitu sekolah menjadikan pendidikan agama sebagai landasan pembelajaran, sedangkan pada sekolah negeri berlandaskan kurikulum sesuai dengan aturan diknas. Aturan pondok pesantren yang mewajibkan santri untuk bermalam di asrama pondok berbeda dengan sekolah negeri yang hanya memberikan jam belajar di sekolah selama kurang lebih 7 jam. Tanggung jawab pada siswa yang belajar di pondok pesantren juga lebih, dikarenakan santri memiliki kewajiban untuk hidup secara mandiri di asrama dan juga memiliki tanggung jawab untuk menyelesaikan target hafalan Al Qur'an.

Keterampilan sosial menurut (Goleman, 2001) yaitu kemampuan mengelola emosi dengan baik ketika berhubungan dengan orang lain serta dengan tepat dapat membaca kondisi dan jaringan sosial, dapat berinteraksi dengan lancar, menggunakan keterampilan-keterampilan ini untuk memimpin, mempengaruhi, bermusyawarah, menyelesaikan konflik, dan untuk bekerjasama dalam tim. Menurut (Minarni, 2012), keterampilan sosial diartikan sebagai keterampilan berkomunikasi dan berinteraksi dengan orang lain.

Aspek keterampilan sosial menurut Caldarella dan Merrel dalam Matson (2009), terdapat lima aspek keterampilan sosial, meliputi manajemen diri (self-management), perilaku assertif (assertion), hubungan dengan teman sebaya (peer relationship), kepatuhan (compliance), dan kemampuan akademis (academic achievement). Faktor yang mempengaruhi keterampilan sosial menurut Samanci dalam Matson (2009) terdiri dari karakteristik individu, keluarga, sekolah, danlingkungan masyarakat. Menurut Asrorun dalam Movanita (2016), remaja sering menghabiskan waktu di sekolah dan memanfaatkan sekolah sebagai tempat bersosialisasi. Remaja membutuhkan interaksi dengan lingkungan sekolah, teman di lingkungan rumah, dan keluarga di rumah. Berdasarkan Pemerintah Indonesia (2003), sistem pendidikan yang terdiri dari negeri dan keagamaan memiliki penyelanggara, aliran dan unsur yang berbeda. Perbedaan kurikulum, metode pembelajaran, lama pembelajaran, tempat tinggal, dan tuntutan tugas dapat mempengaruhi keterampilan sosial siswa.

\section{METODE}

Metode pengumpulan data dalam penelitian ini yaitu menggunakan metode skala. Penelitian ini menggunakan skala keterampilan sosial yang diadaptasi dari skala yang telah disusun oleh Aryani (2015). Skala disusun berdasarkan aspek-aspek dari Caldarella dan Merrel dalam Matson (2009) yaitu keterampilan komunikasi dengan teman sebaya (peer relationship), manajemen diri, kesuksesan akademik, kepatuhan, dan perilaku asertif. Skala keterampilan sosial berjumlah 45 aitem setelah dilakukan uji validitas dan uji reliabilitas. Koefisien validitas didapat dari analisis hasil penilaian expert judgement mengunakan formula aiken's $0,8(\geq 0,8)$. Reliabilitas dengan alpha $(\alpha)$ skala keterampilan sosial yaitu sebesar 0,882 . Teknik pengambilan sampel yang digunakan dalam penelitian ini dengan cluster random sampling (Creswell, 2015). Subjek penelitian ini adalah siswa SMA Negeri X dan santri SMA PPTQ X yang masing-masing sebanyak empat kelas.

\section{HASIL DAN PEMBAHASAN}

Hasil uji normalitas variabel keterampilan sosial pada sekolah negeri diperoleh nilai 
Kolmogrov-Smirnov $\mathrm{Z}=0,080$ dengan $\mathrm{p}=0,125$ ( $\mathrm{p}>0,05)$ yang berarti sebaran data dikatakan normal. Hasil uji normalitas variabel keterampilan sosial pada sekolah pondok pesantren diperoleh nilai Kolmogrov-Smirnov $Z=0,101$ dengan $p=0,051(p>0,05)$ yang berarti sebaran data normal.

Tabel 1.

Hasil uji normalitas

\begin{tabular}{clccc}
\hline \multirow{2}{*}{ Keterampilan } & \multicolumn{3}{c}{ Sistem Pendidikan } & \multicolumn{3}{c}{ Kolmogrov-Smirnov } \\
\cline { 2 - 4 } Sosial & Sekolah Negeri & 0,080 & $\mathrm{df}$ & Sig. \\
& Sekolah Pondok Pesantren & 0,101 & 77 & 0,125 \\
& & & & 0,051 \\
\hline
\end{tabular}

Berdasarkan uji homogenitas menggunakan Levene's Test for Equality of Variance diperoleh nilai $\mathrm{F}=0,895$ dan nilai sig= 0,346 (sig.> 0,05), maka dapat dikatakan bahwa varian data homogen.

Tabel 2.

Hasil uji homogenitas

\begin{tabular}{clcc}
\hline & & \multicolumn{2}{c}{ Levene's Test for Equality } \\
Keterampilan & & $\mathrm{F}$ & Sig. \\
\cline { 3 - 4 } Sosial & Equal variances assumed & 0,895 & 0,346 \\
& Equal variances not assumed & & \\
\hline
\end{tabular}

Berdasarkan nilai t-hitung sebesar 5,744. Rerata keterampilan sosial pada siswa sekolah negeri diperoleh nilai sebesar 138,50 dan nilai rerata keterampilan sosial siswa pada sekolah pondok pesantren sebesar 128,21 . Hasil tersebut menunjukkan bahwa keterampilan sosial siswa sekolah negeri lebih tinggi dibandingkan dengan keterampilan sosial siswa sekolah pondok pesantren.

Tabel 3.

Independent samples test

\begin{tabular}{clccc}
\hline & & \multicolumn{3}{c}{$\mathrm{t}$-test for Equality of Means } \\
& & $\mathrm{T}$ & $\mathrm{df}$ & Sig. (2-tailed) \\
\cline { 3 - 5 } Keterampilan & Equal variances assumed & 5,744 & 173 & 0,000 \\
Sosial & Equal variances not assumed & 5,786 & 167,392 & 0,000 \\
\hline
\end{tabular}

Rerata keterampilan sosial pada siswa sekolah negeri diperoleh nilai sebesar 138,50, sedangkan pada sekolah pondok pesantren sebesar 128,21. Dapat dikatakan bahwa keterampilan sosial siswa sekolah negeri lebih tinggi dibandingkan siswa sekolah pondok pesantren.

Tabel 4 .

Jumlah subyek dan rata-rata

\begin{tabular}{clcc}
\hline \multirow{2}{*}{ Keterampilan } & Sistem Pendidikan & N & Mean \\
\cline { 2 - 4 } Sosial & Sekolah Negeri & 98 & 138,50 \\
& Sekolah Pondok Pesantren & 77 & 128,21 \\
\hline
\end{tabular}

Samanci dalam Matson (2009) menjelaskan faktor yang mempengaruhi keterampilan sosial adalah sekolah. Sekolah sangat berpengaruh terhadap perkembangan sosial dalam hal aktivitas serta 


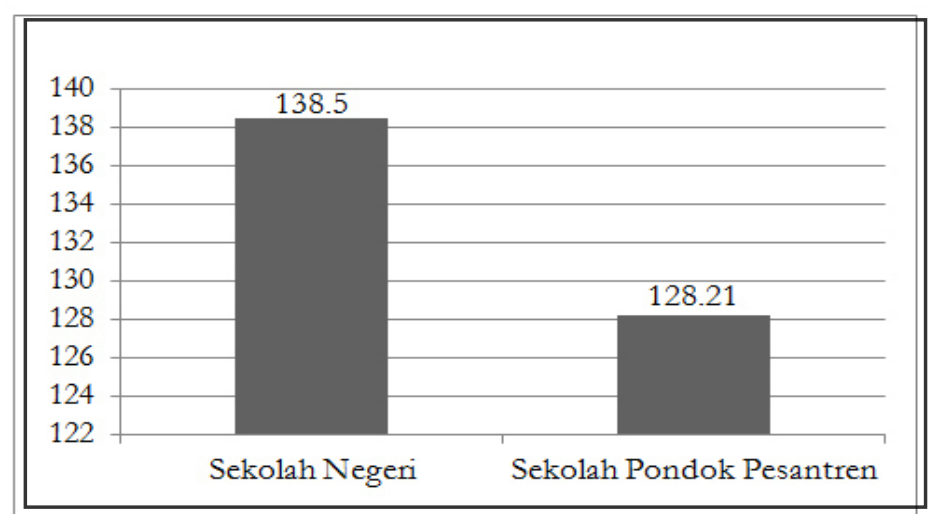

Gambar 1. Perbedaan keterampilan sosial pada sekolah negeri dan pondok pesantren

upaya mengurangi stres terhadap ujian dan tugas. Sugiati (2016) menyatakan bahwa santri tahfidz qur'an memiliki kewajiban hafalan di luar jam pembelajaran yang otomatis memberikan tuntutan dan tugas lebih banyak bagi santri. Tuntutan santri yaitu berupa setoran hafalan, menghafal kitab-kitab dan Al Qur'an (Setyaningsih, 2016). Hal tersebut juga berlaku di SMA PPTQ X yang mengharuskan setiap santri memiliki target hafalan minimal sebanyak 7 juz. Tuntutan tugas tersebut harus dipenuhi oleh siswa sekolah pondok pesantren namun tidak dimiliki oleh sekolah negeri yang menjadikan siswa sekolah pondok pesantren memiliki tuntutan tugas tambahan.

Hasil penelitian tersebut sejalan dengan penelitian sebelumnya oleh Hermaleni et al. (2016) yang menunjukkan bahwa terdapat perbedaan kompetensi sosial siswa boarding school dan siswa sekolah menegah umum reguler dimana kompetensi sosial siswa sekolah menengah umum reguler lebih tinggi daripada siswa boarding school. Selain itu, hasil penelitian lain yang dilakukan oleh Barsihanor dan Hafiz (2016) menyebutkan bahwa adanya perbedaan yang signifikan antara keterampilan sosial siswa sekolah reguler dengan siswa sekolah sehari penuh dimana keterampilan sosial siswa sekolah reguler lebih tinggi dibandingkan sekolah sehari penuh.

Berdasarkan kategorisasi, rerata empirik (RE) keterampilan sosial siswa sekolah negeri dan siswa sekolah pondok pesantren termasuk dalam kategori tinggi. Meskipun termasuk dalam kategori yang sama, namun dilihat dari kategori persentase subjek yang menunjukkan persentase paling besar pada sekolah negeri yaitu sebesar $77 \%$ pada kategori tinggi, sedangkan sekolah pondok pesantren persentase paling tinggi pada kategori sedang yaitu sebesar 51\%. Hal ini mendukung hasil penelitian bahwa keterampilan sosial siswa sekolah negeri lebih tinggi dibandingkan siswa sekolah pondok pesantren.

Data yang ada menyebutkan kegiatan belajar mengajar di SMA Negeri X menghabiskan waktu 5 hari dalam seminggu dengan interval waktu kurang lebih 8 jam setiap harinya di sekolah. Setelah itu, siswa sekolah negeri bebas untuk melakukan kegiatan di luar sekolah seperti mengisi kegiatan dengan les, menyalurkan hobi atau bakat yang dimiliki, bermain dengan teman, serta berinteraksi dengan keluarga dan masyarakat, sedangkan proses belajar mengajar di sekolah Pondok Pesantren Tahfidzul Qur'an X berlangsung selama 6 hari dalam seminggu dengan interval waktu kurang lebih 7 jam dalam sehari.

Berdasarkan hasil wawancara dengan salah satu ustadz pendamping santri didapatkan informasi bahwa kegiatan pembelajaran dimulai pada pukul 07.00 - 14.00 WIB. Kegiatan dilanjutkan sore hari di asrama pondok pesantren. Kegiatan tersebut berupa shalat ashar berjamaah dilanjutkan dengan setoran hafalan kepada pendamping tahfidz. Setelah itu santri diberikan jeda waktu untuk mandi dan sebagainya. Pada waktu shalat maghrib kegiatan dilanjutkan dengan shalat berjama'ah begitu juga pada shalat isya'. Setelah kegiatan selesai, santri diberikan waktu istirahat lalu pada pukul 03.00 WIB kegiatan dilanjutkan dengan shalat malam. Setelah shalat subuh adalah 
waktu santri untuk setoran hafalan lalu dilanjutkan dengan olahraga pagi dan bersiap untuk sekolah. Selanjutnya kegiatan santri dilakukan di sekolah. Kegiatan-kegiatan tersebut sudah terjadwal setiap harinya sesuai dengan aturan pondok.

Uraian kegiatan-kegiatan di atas dapat dikatakan bahwa siswa sekolah negeri memiliki kesempatan yang lebih fleksibel dibandingkan dengan waktu yang dimiliki siswa sekolah pondok pesantren. Siswa sekolah negeri lebih banyak memiliki kesempatan untuk bersosialisasi dan aktualisasi diri di luar kegiatan sekolah, sedangkan waktu yang dimiliki siswa pondok pesantren lebih terbatas karena kegiatan sudah terjadwal dengan aturan pondok.

Faktor yang lain mempengaruhi keterampilan sosial menurut Samanci dalam Matson (2009) yaitu faktor keluarga. Keluarga memiliki pengaruh positif terhadap perkembangan keterampilan sosial. Adanya model perilaku positif dari orang tua, dukungan keluarga, komunikasi di rumah, dan waktu yang berkualitas untuk individu. Siswa yang bersekolah di pondok pesantren diwajibkan untuk tinggal di asrama dan hidup mandiri terpisah dengan orang tua dengan jadwal kepulangan 2 kali selama 1 semester. Sebanyak 16-18 santri pondok pesantren diasuh oleh 1 orang pendamping. Rasio perbandingan antara pendamping dengan santri sebesar 1 banding 16-18. Dengan demikian dapat diperkirakan bahwa perhatian pendamping tergolong kurang memadai.

Dilihat dari jadwal kepulangan, maka santri memiliki waktu yang relatif sedikit untuk bertemu dengan orang tua. Dilihat dari jumlah perbandingan pendamping dengan santri, pendamping tidak hanya memiliki satu santri yang harus diasuh, maka pendamping harus membagi perhatian kepada semua santri yang diasuh. Berbeda dengan siswa sekolah negeri yang sebagian besar tinggal bersama orang tuanya. Siswa yang tinggal bersama orang tua memiliki lebih banyak kesempatan untuk mendapatkan dukungan dan dapat berkomunikasi secara langsung dengan orang tua. Berdasarkan hasil wawancara dengan siswa sekolah negeri didapatkan informasi bahwa siswa lebih memiliki kualitas waktu yang dihabiskan bersama orang tua, misalnya siswa dapat menceritakan secara langsung kegiatannya sehari-hari, mendapatkan pengawasan secara langsung dari orang tua, dan siswa juga dapat mencontoh model perilaku positif dari orang tua secara langsung. Menurut hal tersebut, mendukung hasil penelitian yang menyatakan bahwa keterampilan sosial siswa pondok pesantren lebih rendah dibandingkan siswa sekolah negeri.

Hurlock (2002) menyatakan bahwa semakin banyak partisipasi sosial, maka semakin besar kompetensi sosial remaja. Partisipasi sosial remaja dapat menjadikan wawasan sosial remaja menjadi semakin baik, sehingga remaja dapat menilai teman-temannya dan lingkungannya dengan baik. Lingkungan sosial sekolah negeri memiliki perbedaan dengan lingkungan sosial sekolah pondok pesantren dimana siswa sekolah negeri bersekolah dan tinggal di dua lingkungan yang berbeda, sedangkan siswa pondok pesantren bersekolah dan bertempat tinggal di lingkungan yang sama. Hal tersebut memberikan kesempatan yang lebih besar kepada siswa sekolah negeri untuk berpartisipasi sosial pada lingkungan yang berbeda yang mereka inginkan dan bebas tanpa ada aturan baku yang mengikat. Berbeda dengan siswa pondok pesantren yang tinggal di lingkungan homogen yaitu pada lingkungan yang sama dimana situasi sosial kurang bervariasi dan terikat dengan aturan baku. Hal ini akan mempengaruhi keterampilan sosial siswa karena partisipasi sosial dan wawasan sosial mempengaruhi keterampilan sosial.

\section{SIMPULAN}

Berdasarkan hasil penelitian ini, dapat disimpulkan bahwa t-hitung sebesar 5,744 dan nilai sig.p sebesar 0,000, maka dapat diartikan bahwa ada perbedaan keterampilan sosial yang sangat signifikan antara siswa sekolah negeri dan siswa sekolah pondok pesantren, dimana keterampilan 
sosial siswa sekolah negeri lebih tinggi dibandingkan sekolah pondok pesantren dengan rerata sekolah negeri sebesar 138,50 dan rerata sekolah pondok pesantren sebesar 128,21. Rerata empirik sekolah negeri sebesar 138,50 dan rerata hipotesis sebesar 112,50. Hasil tersebut dapat dikatakan bahwa keterampilan sosial siswa tergolong tinggi. Persentase jumlah terbanyak pada kategori tinggi. Rerata empirik sekolah pondok pesantren sebesar 128,21 dan rerata hipotesis sebesar 112,50. Hasil tersebut dapat dikatakan bahwa keterampilan sosial siswa tergolong tinggi. Persentase jumlah terbanyak pada kategori sedang.

Bagi siswa sekolah negeri, keterampilan sosial dapat dipertahankan dengan cara tetap menjalin hubungan sosial yang baik dengan guru, teman, orang tua, dan lingkungan. Seperti halnya aktif dalam kegiatan berorganisasi, baik di sekolah maupun di masyarakat karena hal tersebut dapat melatih kemampuan siswa untuk berkomunikasi, berinteraksi, manajemen diri, dan menambah relasi. Bagi siswa sekolah pondok pesantren, keterampilan sosial diharapkan dapat meningkat dengan cara mengikuti organisasi maupun ekstrakulikuler di sekolah seperti kegiatan mukhoyyam yang dapat memupuk jiwa kepemimpinan dan kedisiplinan. Siswa sekolah pondok pesantren juga dapat mengadakan kegiatan halaqoh antar siswa yang dapat digunakan sebagai sarana untuk berbagi pengalaman, cerita, dan untuk menambah keakraban.

Bagi guru, diharapkan untuk dapat mempertahankan keterampilan sosial siswa dengan cara memaksimalkan metode active learning yang telah ada misalnya dengan cara diskusi, presentasi, dan roleplay. Cara tersebut diharapkan membuat siswa lebih aktif dan keterampilan sosial mereka dapat terasah. Bagi guru pondok pesantren, diharapkan untuk dapat meningkatkan keterampilan sosial siswa dengan cara tetap menjalankan kegiatan yang selama ini telah terprogram seperti kegiatan mukhoyyam, kedisiplinan, latihan dasar kepemimpinan, outing class, mastasia (masa ta'aruf), bakti sosial, berbagi berkah qurban, buka puasa bersama warga, berbagi takjil keliling, dan outing class secara intens.

Bagi orang tua siswa sekolah negeri, diharapkan turut berpartisipasi dalam mempertahankan keterampilan sosial siswa dapat dengan cara memberi contoh perilaku positif, aktif menanyakan kegiatan sehari-hari anaknya, menjadi tempat yang nyaman bagi anak untuk berkeluh kesah atau menceritakan permasalahan, memberi motivasi, nasihat, dan berbagi pengalaman. Bagi orang tua siswa pondok pesantren, diharapkan untuk turut berpatisipasi dalam meningkatkan keterampilan sosial siswa dengan cara orang tua aktif berkomunikasi dengan pihak ustadz atau ustadzah menanyakan tentang perkembangan siswa. Ketika siswa libur dan pulang ke rumah orang tua, diharapkan untuk memberikan perhatian misalnya dengan mencurahkan perhatian dan memfasilitasi kebutuhan anak. Orang tua dapat memberikan nasihat, motivasi, serta dukungan sebelum anak kembali ke pondok.

Bagi peneliti lain yang akan melakukan penelitian dengan topik yang sama, diharapkan dapat melakukan penelitian secara lebih mendalam terutama mengkaji aspek-aspek sistem pendidikan yang dominan dan mempengaruhi keterampilan sosial.

\section{REFERENSI}

Anam, C., \& Suharningsih, S. (2014). Model Pembinaan Disiplin Santri (Studi Kasus Pondok Pesantren Darul Fiqhi Kabupaten Lamongan). Jurnal Kajian Moral dan Kewarganegaraan, 2(2), 469-483. Diambil dari http://jurnalmahasiswa.unesa.ac.id/index.php/jurnalpendidikan-kewarganegaraa/article/view/7843

Aqdwirida, R. (2016). Implementasi Kurikulum 2013 di SMA Negeri 2 Magelang. Jurnal Kebijakan 
Pendidikan, 5(1), 34-38. Diambil dari http://journal.student.uny.ac.id/ojs/index.php/ sakp/article/view/1420

Aryani, E. (2015). Korelasi antara keterampilan sosial dengan resiliensi pada siswa kelas XII SMK Negeri 1 Salam pasca bencana lahar dingin merapi. Universitas Negeri Yogyakarta.

Bakhtiar, M. I. (2015). Pengembangan video ice breaking sebagai media bimbingan konseling dalam meningkatkan keterampilan sosial. Jurnal Psikologi Pendidikan dan Konseling: Jurnal Kajian Psikologi Pendidikan dan Bimbingan Konseling, 1(2), 150-162. https://doi.org/10.26858/ jpkk.v1i2.1816

Barsihanor, \& Hafiz, A. (2016). Studi komparasi keterampilan sosial antara siswa sekolah dasar yang menggunakan sistem full day dan reguler. Muallimuna, 2(1), 95-103. Diambil dari https://www.neliti.com/id/publications/222471/studi-komparasi-keterampilan-sosialantara-siswa-sekolah-dasar-yang-menggunakan

Creswell, J. W. (2015). Research design: Pendekatan kualitatif, kuantitatif, dan mixed. Yogyakarta: Pustaka Pelajar.

Goleman, D. (2001). Kecerdasan emosi untuk mencapai puncak prestasi. Jakarta: Gramedia Pustaka Utama.

Hermaleni, T., Mudjiran, \& Zamzami, A. (2016). Perbedaan kompetensi sosial siswa boarding school dan siswa sekolah umum reguler. Jurnal RAP (Riset Aktual Psikologi), 7(1), 90-98. https://doi.org/10.24036/rapun.v7i1.6611

Hurlock, E. B. (2002). Psikologi perkembangan: Suatu pendekatan sepanjang rentang kehidupan. Jakarta: Erlangga.

Majorsy, U., Kinasih, A. D., Andriani, I., \& Lisa, W. (2013). Hubungan antara keterampilan sosial dan kecanduan situs jejaring sosial pada masa dewasa awal. Proceeding PESAT (Psikologi, Ekonomi, Sastra, Arsitektur \& Teknik Sipil), 5, 78-84. Diambil dari https://media.neliti. $\mathrm{com} /$ media/publications/172566-ID-hubungan-antara-keterampilan-sosial-dan.pdf

Matson, J. L. (2009). Social behavior and skill in children. New York: Springer.

Minarni, A. (2012). Pengaruh pembelajaran berbasis masalah terhadap kemampuan pemahaman matematis dan keterampilan sosial siswa smp negeri di Kota Bandung. Jurnal Pendidikan Matematika, 6(2), 162-174. https://doi.org/10.24114/paradikma.v6i2.1077

Mota, C. P., \& Matos, P. M. (2013). Peer attachment, coping, and self-esteem in institutionalized adolescents: the mediating role of social skills. European Journal of Psychology of Education, 28(1), 87-100. https://doi.org/10.1007/s10212-012-0103-z

Movanita, A. N. K. (2016). KPAI anggap "full day school" akan ganggu kehidupan sosial anak. Diambil dari Kompas website: https://nasional.kompas.com/read/2016/08/09/12463051/ kpai.anggap.full.day.school.akan.ganggu.kehidupan.sosial.anak

Papalia, D. E., \& Feldman, R. D. (2014). Menyelami perkembangan manusia. Jakarta: Salemba Humanika.

Pemerintah Indonesia. (2003). Undang-undang Republik Indonesia nomor 20 tahun 2003. 
Sari, R. N., \& Suryanto. (2016). Kecerdasan emosi, anonimitas, dan cyberbullying (bully dunia maya). Persona: Jurnal Psikologi Indonesia, 5(01), 48-61. https://doi.org/10.30996/persona. v5i01.741

Setyaningsih, R. (2016). Kontinuitas pesantren dan madrasah di Indonesia. At Ta'Dib, 11(1), 167183. https://doi.org/10.21111/at-tadib.v11i1.651

Sugiati. (2016). Implementasi metode sorogan pada pembelajaran tahsin dan tahfidz pondok pesantren. Qathrunâ, 3(01), 135-160. Diambil dari http://jurnal.uinbanten.ac.id/index. php/qathruna/article/view/17 